\title{
Kesiapan Petani Kelapa Sawit Swadaya dalam Implementasi ISPO: Persoalan Lingkungan Hidup, Legalitas dan Keberlanjutan
}

\author{
Arya Hadi Dharmawan¹, Fredian Tonny Nasdian², Baba Barus¹, Rilus A. Kinseng², \\ Yoyoh Indaryanti ${ }^{1}$, Hana Indriana², Dyah Ita Mardianingsih1, Faris Rahmadian1, Hilda \\ Nurul Hidayati², Ade Mirza Roslinawati²
}

1Pusat Studi Pembangunan Pertanian dan Pedesaan, Institut Pertanian Bogor, Bogor Tengah, Kota Bogor, Jawa Barat 16129; e-mail: adharma1963@gmail.com

2Departemen Sains Komunikasi dan Pengembangan Masyarakat, Fakultas Ekologi Manusia, Institut Pertanian Bogor 16680

\begin{abstract}
ABSTRAK
Ekspansi lahan perkebunan kelapa sawit berlangsung sangat cepat di Indonesia dalam dua dekade terakhir yang memberikan sejumlah resiko terhadap sumberdaya alam dan lingkungan hidup.Resiko tersebut terutama perubahan lanskap, ekosistem dan sistem matapencaharian masyarakatnya.Dalam rangkamenekanresiko terhadap alam dan lingkungan, kepada setiap aktivitas perkebunan diterapkan sejumlah standar keberlanjutan yang harus dipatuhi.Salah satu sistem tata kelola perkebunan yang memastikan standar keberlanjutan (sustainability standards)adalah sertifikasi ISPO (Indonesia Sustainable Palm Oil). Namun demikian, implementasi ISPOmasih terbatas dan bersifat sukarela (voluntary).Indonesia segera mengimplementasikan, sertifikasi ISPO secara wajib kepada setiap pelaku perkebunan dan industri pengolahan kelapa sawit. Pertanyaannya seberapa jauh kesiapan (readiness) petani kelapa sawit swadaya dalam menghadapi ISPO?Penelitian ini hendak mengetahui kesiapan petani pada beberapa parameter ISPO yaitu legalitas tanah, legalitas benih, dan pengetahuan petani tentang pengelolaan lingkungan. Penelitian ini dilakukan di beberapa desa di tiga lokasi, yaitu di Provinsi Riau, Kalimantan Tengah dan Kalimantan Timur.Sejumlah responden dipilih secara acak sederhana, sebagai sampel untuk setiap desa penelitian. Hasil penelitian menunjukkan bahwa berdasarkan parameter legalitas tanah, legalitas benih, dan pengetahuan petani tentang pengelolaan lingkungan menunjukkan bahwa petani sawit skala kecil di tiga lokasi penelitian tidak siap untuk melaksanakan sertifikasi ISPO.Analisis Gap pada penelitian ini menunjukkan bahwa terdapat beda yang sangat signifikan antara harapan dengan kenyataan untuk aspek-aspek yang menjadi parameter ISPO. Struktur nafkah rumahtangga petani kelapa sawit swadaya muncul dalam dua tipe yakni rumahtangga dengan kontribusi kelapa sawit yang dominan dan struktur nafkah yang beragam (kelapa sawit tidak dominan).Sertifikasi ISPO beresiko terhadap rumahtangga yang memiliki struktur nafkah yang beragam karena berpotensi membebani sumber nafkah non kelapa sawit.Dengan demikian, resiko ekspansi lahan perkebunan kelapa terhadap sumberdaya alam dan lingkungan hidup, tetap akan menjadi tantangan besar ke depan.
\end{abstract}

Kata kunci:Sertifikasi ISPO, petani kelapa sawit swadaya, legalitas, struktur nafkah, analisis gap

\section{ABSTRACT}

The expansion of oil palm plantations run very quickly within two decades in Indonesia.It provides a certain amount of risk against natural resources and the environment. These risks are mainly landscape changes, ecosystems changes and livelihood system change of the rural society. In order to suppress risk, sustainability standards for plantation operation, needs to be implemented. One of theinstruments that ensuresustainability standards is ISPO (Indonesia Sustainable Palm Oil). However, its implementation is still limited to be voluntary. In the near future, ISPO will be implemented as mandatory for all business model of oil palm plantation as well as for oil palm mills.This research is about to find out the readiness of the oil palm smallholdersto implement ISPO, in particular with regard to the parameters of land seeds legality, land legality, and knowledge on the management of the environment. This research was conducted in several villages in three locations, namely in Riau, Central Kalimantan and East Kalimantan Province. A number of respondents were withdrawn from each village and were selected using simple random sampling method. The results showed that land legality parameter, legality of the seed, and knowledge of oil palm smallholders about environmental management revealsunreadiness of the smallholder to carry out ISPO certification. Gap analysis showed that there is a very significant difference between expectations and realities for all parametersofISPO. The livelihood structure of independent oil palm smallholders appear in two types i.e., households with dominant contribution of oil palm and households with diverse livelihood structures (where oil palm is not dominant). ISPO certification is potentially causing problems to households for those having diverse livelihood structure because it has the potential to burden non-oil palm income.Thus, the risk of aoil palm plantation expansion towards natural resources and the environment, will still be a great challenge in the future.

Keywords: ISPO certification, oil palm smallholders, legality, livelihood structure, gap analysis

Citation: Dharmawan, A. H., Nasdian, F. T., Barus, B., Kinseng, R. A., Indaryanti, Y., Indriana, H., Mardianingsih, D. I., Rahmadian, F., Hidayati, H. N., dan Roslinawati, A. M. (2019). Kesiapan Petani Kelapa Sawit Swadaya dalam Implementasi ISPO: Persoalan Lingkungan Hidup, Legalitas dan Keberlanjutan. Jurnal Ilmu Lingkungan, 17(2), 304-315, doi:10.14710/jil.17.2.304-315 


\section{Pendahuluan}

\subsection{Latar Belakang}

Selaras dengan ekspansi luas lahan perkebunan kelapa sawit yang terus meningkat, maka industri pengolah tandan buah segar (TBS) dan industri minyak sawit di Indonesia cenderung mengalami peningkatan sejak satu dekade terakhir.Jumlah produksi perkebunan sawit di Indonesia pada tahun 2016adalah 33,23 juta ton, yang dihasilkan dari 11,91 juta Ha luas total areal perkebunan kelapa sawit secara nasional. Secara proporsional, 54,64 persen kebun sawit nasional diusahakan oleh perusahaan besar swasta (PBS). Sisanya, sekitar 39,08 persen diusahakan oleh rakyat (termauk plasma) dan sebagian kecil diusahakan oleh perkebunan besar milik negara (PBN) (Ditjen Perkebunan, 2015-2017).

Kecenderungan perkembangan luas areal kelapa sawit di Indonesia terus mengalami peningkatan signifikan dari hanya 294,56 ribu hektar pada tahun 1980 menjadi 11,30 juta hektar pada tahun 2015 . Peningkatan luas area kelapa sawit terbesar terjadi pada periode sebelum krisis moneter (tahun 19801997) dengan laju pertumbuhan sebesar 14,68 persen per tahun. Pertumbuhan yang signifikan terjadi pada luas areal kelapa sawit rakyat (smallholders) dan PBS masing-masing sebesar 46,85 persen per tahun dan 19,79 persen per tahun. Sentra produksi minyak sawit Indonesia terutama berasal dari enam provinsi yang memberikan kontribusi sebesar 73,69 persen terhadap total produksi minyak sawit Indonesia. Provinsi Riau dan Sumatera Utara merupakan provinsi sentra produksi CPO terbesar di Indonesia dengan kontribusi masing-masing sebesar 23,75 persen dan 16,24 persen (Kementerian Pertanian, 2016).Ekspansi lahan perkebunan sawit adalah kata-kunci yang penting untuk mulai memahami semesta persoalan kelapa sawit di Indonesia.

World Growth (2011) melaporkan bahwa industri kelapa sawit Indonesia telah lama mendapat kecaman dari sejumlah Lembaga Swadaya Masyarakat (LSM) yang berkampanye menentang industri ini.Inti kecaman adalah ekspansi perkebunan yang dinilai berlangsung dalam waktu cepat dan massive.Ekspansi tersebut telah dianggap bertanggungjawab atas terjadinya penggundulan hutan (deforestasi), emisi karbon, dan hilangnya keanekaragaman hayati (Pearce, 2017; Gaveau et al., 2016).Selaras dengan hal itu, muncul tudingan yang meluas bahwa industri minyak kelapa sawit sebagai tidak berkelanjutan (unsustainable). Sebagai akibatnya, ada desakan untuk menghentikan atau membatasi semua konversi lahan hutan (untuk perkebunan kelapa sawit) di masa depan.Berbagai desakan ini kelak direspons oleh kebijakan moratorium perluasan perkebunan sawit oleh Pemerintah Republik Indonesia.Kebijakan itu tertuangdalam Instruksi Presiden Republik Indonesia, No 8 Tahun 2018 tentang "Penundaan dan Evaluasi Perkebunan Kelapa Sawit serta Peningkatan Produktivitas Perkebunan Kelapa Sawit".
Saat ini Indonesia merupakan negara ketiga terbesar di dunia yang mengeluarkan emisi gas rumah kaca yang membahayakan iklim dimana 85 persen dari gas-gas tersebut dihasilkan akibat penggarapan lahan yang sebagian besar dilakukan dengan penebangan hutan hujan tropis dan perusakan tanah gambut (Greenpeace, 2010). Perluasan perkebunan kelapa sawit dianggap ikut bertanggung jawab terhadap emisi gas rumah kaca, karena ekspansi perkebunan kelapa sawit ditengarai memasuki juga kawasan yang tidak diperbolehkan untuk berkebun.Perusahaan perkebunan rakyat skala besar dan kecildianggap berperansertadalam mendorong pertumbuhan ekonomi yang memberikan resiko terhadap lingkungan hidup.Dalam rangka menekan resiko pada kerusakan sumberdaya alam dan lingkungan, maka apapun model bisnis perkebunan kelapa sawit diharuskan menerapkan prinsip-prinsip tata kelola produksi yang baik (good-governance).Penerapan standar keberlanjutan melalui implementasi tata kelola produksi yang baik, pada dasarnya adalah upaya menginternalisasikan biaya-biaya eksternalitas negatif yang dihasilkan sebagai resiko dari aktivitas produksi sedemikian sehingga kehancuran lingkungan dapat diminimalisir (Sanda et al., 2005; Pierre, 2000; Scherr, 2004).Masalah lingkungan hidup terkait dengan usaha kelapa sawit diantaranya adalah masalah deforestasi, biodiversitas dan perubahan iklim (Teoh, 2010; Pearce, 2017; Gaveau et al., 2017). Beberapa waktu terakhir, proses alih fungsi hutan alam dan lahan gambut berkontribusi negatif berupa degradasi lahan gambut, degradasi sumberdaya air, dan kehilangan keanekaragaman hayati.Pembangunan kelapa sawit juga diklaim terkadang tidak sesuai dengan peraturan rencana tata ruang sebagaimana seringditemukan kebun kelapa sawit di kawasan dengan nilai konservasi tinggi (di kawasan lindung).

Untuk menekan resiko itu, diterapkan sistem tatakelola (sertifikasi) perkebunan kelapa sawit yang dapat diimplementasikan secara luas namun mudah pada baik perusahaan perkebunan swasta besar, industri pengolahan, maupun petani kelapa sawit rakyat (smallholders) di Indonesia agar tunduk pada prinsip-prinsip sustainability. SertifikasiIndonesian Sustainable Palm Oil (ISPO) hadir sebagai alternatif yang menawarkan instrumen penilaian dan pengelolaan perkebunan kelapa sawit untuk menanggulangi resiko lingkungan sekaligus isu rendahnya kredibilitas produksi di pasar internasional (terutama Eropa)yangsaat ini masih menjadi tantangan bagi perkebunan kelapa sawit utamanya perkebunan kelapa sawit rakyat (smallholders).

Implementasi ISPO untuk mewujudkan industri kelapa sawit yang berkelanjutan tentunya akan menghadapi berbagai kendala yang harus dikaji secara komprehensif, sehingga diperlukan penelitian yang mendalam tentang kesiapan para petani kelapa sawit rakyat dalam mempersiapkan dan 
mengimplementasikan sertifikasi ISPO dengan segenap prinsip-prinsipnya.

\subsection{Rumusan Masalah}

Produk kelapa sawit di Indonesia mengalami persoalan kredibilitas di pasar internasional karena persoalan lingkungan hidup, deforestasi dan degradasi hutan yang dilekatkan pada perkebunan kelapa sawit (Obizinski et al., 2012; Brandi et al., 2013; Setiawan et al., 2016). Persoalan lingkungan hidup yang negatif berujung pada market-acceptance produk sawit CPO (Crude Palm Oil) dari Indonesia yang menghadapi banyak masalah (Jelsma etal., 2017) terutama di Eropa. Sejauh ini Indonesia menghadapi Banning Policy dari European Union terhadap produk sawit (terutama produk biodiesel) yang datang dari Indonesia.Pasar internasional menganggap bahwa ekspansi perkebunan kelapa sawit rakyatmenimbulkan persoalan ketidakberlanjutan ekologi sebagai akibat monocropping system yang mengganggu biodiversity (Khatun et al., 2017; Ocampo-Penueala, 2018; Scriven et al., 2018), hidrology (Silalertruksa et al., 2017), serta sengketa lahan (Abram et al., 2017).

Standar-standar keberlanjutan perlu ditetapkan sebagai bagian untuk menetralisasi resiko sosial dan ekologi/lingkungan dari ekspansi perkebunan kelapa sawit.Di Indonesia adalah ISPO (Indonesia Sustainable Palm Oil) diajukan sebagai inisiatif untuk menekan resiko lingkungan atas perluasan lahan kelapa sawit.ISPO sebenarnya sudah ditetapkan oleh pemerintah RI melalui Peraturan Menteri Pertanian Republik Indonesia Nomor 11. Permentan/ OT.140/3/2015.Namun, sejauh ini ISPO sebagai instrument tatakelola produksi sawit, masih bersifat voluntary, sehingga belum cukup efektif menekan keseluruhan resiko. Fakta menunjukan bahwa hingga tahun 2017, jumlah koperasi petani kelapa sawit swadaya yang mengikuti sertifikasi ISPO tidak lebih dari 10 koperasi dari ratusan koperasi yang ada di seluruh Indonesia.Hal ini selain dikarenakan sifat sertifikasi ISPO yang tidak mengikat, juga karena petani sawit sejatinya belum siap untuk mengimplementasikan prinsip-prinsip dalam sertifikasi ISPO.

Beberapa persoalan yang dihadapi oleh petani sawit swadaya atau petani kelapa sawit rakyat(smallholders) dalam mengimplementasikan sertifikasi ISPO antara lain: a) persoalan legalitas lahan yang sangat kompleks; b) legalitas bibit yang bermasalah, karena asal bibit yang tidak berasal dari produsen bibit bersertifikat; dan c) persoalan pengetahuan manajemen lingkungan hidup yang masih sangat terbatas dimiliki oleh smallholders.Poin terakhir terkait masih banyaknya terjadi kebakaran lahan sebagai akibat salah kelola kebun kelapa sawit (Purnomo et al., 2017). Penelitian lain mengungkap bahwa petani sawit swadaya perlu dididik tentang prinsip-prinsip konservasi sumberdaya alam terutama penghargaan pada keanekaragaman hayati (Saadun et al., 2018) untuk menjamin keberlanjutan.
Mengingat ekspansi perkebunan kelapa sawit yang terus berlanjut dan dalam kecepatan cepat, maka dalam waktu dekat instrumen ISPO akan diberlakukan secara mandatory oleh pemerintah. Hal ini berarti bahwa seluruh stakeholder produsen yang terlibat dalam produksi sawit harus menerapkan sertifikasi ISPO tanpa terkecuali. Persoalan-pesoalan yang dihadapi oleh petani sawit swadaya di atas, diperkirakan akanmelambat manakala ISPO dapat diimplementasikan di lapangan. Namun demikian, implementasi ISPO tidak mudah karena readiness to implement sertifikasi yang sangat rendah (Brandi et al., 2013; Dauvergne, 2018; Purnomo et al., 2017, Pacheco et al., 2018; Saadun at.al, 2018).

\subsection{Pertanyaan Penelitian}

Pertanyaan dalam penelitian ini antara lain:

1. Seberapa baik gambaran struktur nafkah Rumahtangga petani kelapa sawit rakyat/swadaya jika dikaitkan dengan kesiapan untuk mengimplementasikan sertifikasi ISPO?

2. Seberapa siap rumahtangga petani sawit dalam implememtasi ISPO terutama dalam hal aspeklegalitas lahan, legalitas bibit, dan pengetahuan petani tentang manajemen lingkungan hidup memiliki kaitan dengan kesiapan petani kelapa sawit swadaya untuk sertifikasi ISPO?

\section{Metodologi Penelitian}

Studi ini dilakukan pada sentra perkebunan kelapa sawit rakyat (smallholders) di tiga desa.Ketiga desa tersebut adalah Desa NTB di Provinsi Kalimantan Tengah, Desa BLG di Provinsi Kalimantan Timur dan Desa BKM di Provinsi Riau.Lokasi studi ditetapkan secara sengaja, dengan pertimbangan bahwa ketiga lokasi tersebut termasuk dalam kelompok (cluster) lima besar sentra perkebunan kelapa sawit di Indonesia. Berdasarkan data dari Kementerian Pertanian dalam Outlook Kelapa Sawit di Indonesia, Provinsi Riau merupakan provinsi sentra produksi CPO terbesar di Indonesia dengan kontribusi sebesar 23,75\%. Sementara Kalimantan Tengah memberikan kontribusi sebesar 10,96\% untuk produksi CPO di Indonesia. Pemilihan lokasi ini juga didukung oleh data statistik yang menunjukkan bahwa Provinsi Riau adalah provinsi dengan luas perkebunan kelapa sawit swadaya terbesar yaitu 1.386 .575 Ha dengan produksi kelapa sawit sebanyak 3.677.989 ton (Direktorat Jenderal Perkebunan, 2016). Sementara Provinsi Kalimantan Tengah dan Kalimantan Timur memliki luasan perkebunan kelapa sawit swadaya masing-masing sebesar 150.059 Ha dan 307.209 Ha dengan produksi kepala sawit masing-masing sebanyak 234.627 ton dan 492.922 ton (Direktorat Jenderal Perkebunan, 2016). Luas perkebunan kelapa sawit swadaya menjadi penting untuk dipertimbangkansebagai parameter studi karena studi ini bertujuan untuk mengukur seberapa besar kesiapan petani kelapa sawit swadaya menghadapi kebijakan Indonesian Sustainable Palm Oil (ISPO). 
Studi ini berfokus pada smallholders, mengingat jumlahnya yang sangat substansial dan melakukan ekspansi yang cukup cepat secara sporadik dan hampir tidak terkendali karena skalanya yang kecil tetapi menyebar.Ketiga desa yang dipilih sebagai kasus dalam studi ini diharapkan mewakili desa-desa dengan rumahtangga petani sawit swadaya yang memiliki kompleksitas persoalan pada aspek legalitas lahan, bibit dan pengelolaan lingkungan hidupserta struktur nafkah yang khas.Ketiga desa ini secara faktual berada di kawasan yang berbatasan dengan kawasan lindung, sehingga interaksi (resiko ekspansi) perkebunan terhadap kawasan lindung terlihat cukup intensif.Fakta lapanganmemperlihatkan bahwa beberapa bagian dari kebun kelapa sawit milik rumahtangga petani berada di dalam kawasan hutan yang secara hukum agraria dinyatakan ilegal. Penetrasi perkebunan kelapa sawit ke dalam kawasan hutan menjadi tantangan besar isu keberlanjutan produksi kelapa sawit, utamanya terkait dengan aktivitas deforestasi (Schouten and Glasbergen, 2011; Wicke et al., 2011; Hansen et al., 2015) dan alih fungsi lahan serta perubahan lanskap ekologi kawasan (Wicke et al., 2011; Gatto et al., 2015; Hansen et al., 2015; Euler et al., 2017) yang mengkhawatirkan.

Data yang dikumpulkan meliputi data primer dan data sekunder.Data primer dikumpulkan melalui metode survai dengan menggunakan kuesioner dan wawancara mendalam (indepth interview) dengan menggunakan pedoman wawancara. Pengambilan sampel untuk metode survei dilakukan terhadap rumah tangga petani kelapa sawit yang sudah melakukan budidaya kelapa sawit minimal lima tahun (telah menghasilkan) dan sudah panen minimal satu kali panen. Pemilihan responden dipilih secara acak sederhana yaitu sebanyak 34 responden untuk masing-masing desa penelitian. Jumlah ini dipilih dengan asumsi sudah memenuhi jumlah minimum responden yang harus disurvey yang dihasilkan oleh perhitungan dengan rumus Slovin, dengan margin of error sebesar 20\%.Jumlah populasi rumahtangga petani kelapa sawit swadaya di masingmasing lokasi ialah Desa NTB sebanyak 1.374 kepala keluarga (BPS Kabupaten Kotawaringin Timur, 2017), Desa BLG sebanyak 499 kepala keluarga (BPS Kabupaten Pelalawan, 2017), dan Desa BKM sebanyak 592 kepala keluarga (Kelurahan Bukit Merdeka, 2017).Dengan demikian total jumlah responden adalah 102 rumahtangga petani dianggap telah memenuhi jumlah minimal responden yang harus diambil. Kerangka sampling dari studi ini adalah rumahtagga petani yang kebunnya berada dan tinggal di desa tersebut. Sampel rumahtangga petani diambil secara acak sederhana, dimana setiap rumahtangga mempunyai kesempatan yang sama untuk dipilih sebagai sampel (Mantra dan Kasto, 1989). Beberapa informan kunci diwawancara untuk memberikan gambaran mendalam atas apa yang terjadi dengan perkebunan kelapa sawit di desa masing-masing. Sementara data sekunder diambil dari berbagai referensi yang relevan.
Analisis data dalam penelitian ini meliputi: 1) struktur nafkah di tiga desa untuk melihat apakah pendapatan yang berasal dari perkebunan kelapa sawit mencukupi dalam mendukung dalam program sertifikasi ISPO; 2) analisis tentang legalitas meliputi tiga aspek legalitas yang dipersyaratkan yaitu legalitas lahan, bibit, dan lingkungan; dan 3) melihat bagaimana (kemungkinan)implementability dan operasionalisasi sertifikasi ISPO pada petani kelapa sawit swadaya atau smallholders di tiga desa penelitian. Pada dasarnya terdapat tujuh prinsip penilaian ISPO, namun dalam penelitian ini hanya dibatasi pada ruang lingkup implementasi prinsip ISPO yang berlaku bagi smallholders saja yaitu aspek livelihood legalitas lahan, bibit, dan lingkungan hidup.Studi ini dimulai dengan penyusunan proposal kegiatan pada bulan Febuari 2017,kemudianstudi lapangan dimulai dengan melakukan kegiatan pra survey pada bulan Agustus-September 2017 dan kegiatan pengambilan data lapang dilakukan pada bulan November serta Desember2017. Hasil studi telah dipresentasikan secara ilmiah pada berbagai forum mulai Juni 2018 hingga awal 2019.

\section{Hasil dan Pembahasan \\ 3.1 Struktur Nafkah}

Terdapat asumsi (dugaan) yang dipegang oleh studi ini bahwa semakin dominan sumber nafkah dari sektor perkebunan kelapa sawit di dalam struktur nafkah rumahtangga petani, maka kesiapan rumahtangga petani sawit untuk mengimplementasikan sertifikasi ISPO akan semakin baik. Sementara itu, fakta menunjukkan bahwa jarang dijumpai rumahtangga petani kelapa sawit swadaya, dengan struktur nafkahnya yang sematamata hanya didukung oleh sumber nafkah yang tunggal, kelapa sawit saja.Diversifikasi nafkahbagi kebanyakan petani di pedesaanadalah upaya rumahtangga dalam bertahan hidup, menekan resiko dari krisis, sambiltetap berupaya meningkatkan kesejahterannya (Feintrenie, Chong, \& Levang, 2012; Sayer et al., 2012). Dengan struktur nafkah yang diversified, maka dominasi kelapa sawit menjadi sangat menentukan dorongan petani untuk terlibat dalam sertifikasi.

Jamak diketahui bahwa pada rumahtangga petani di pedesaan negara sedang berkembang, biasanya terdapat tiga sumber nafkah yaitu farm income, off farm income, dan non farm income yang dimanfaatkan sedemikian rupa untuk mempertahankan eksistensi kehidupannya serta merespon tekanan atau perubahan dari kondisi sekitar (Ellis, 2000; Dharmawan, 2007; Scoones, 1998). Dalam kajian ini sumber nafkah, mengikuti pola di atas, tetapiakan disederhanakan menjadi tiga sumber yaitu perkebunan kelapa sawit (oil palm), petanian secara umum (agriculture), dan non farm activities (semua aktivitas nafkah di luar sector pertanian). Studi di tiga desa penelitian menunjukkan struktur nafkah sebagaimana pada Gambar 1. 


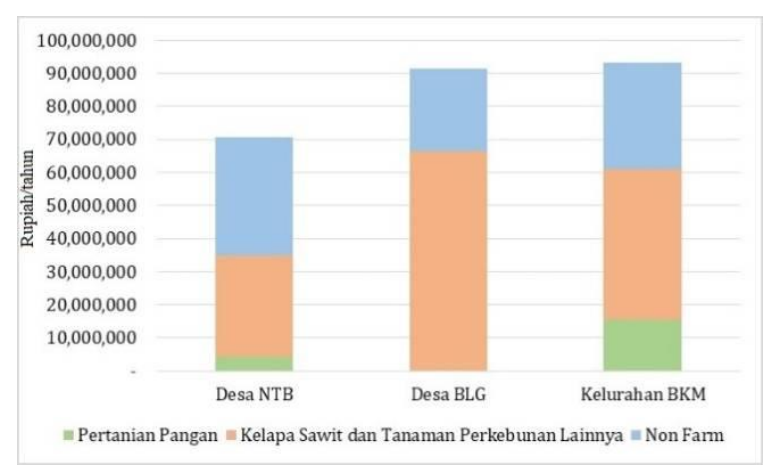

Gambar 1. Struktur Nafkah Rumah tanggaPetani Kelapa Sawit Swadaya di Tiga Desa Penelitian, 2017

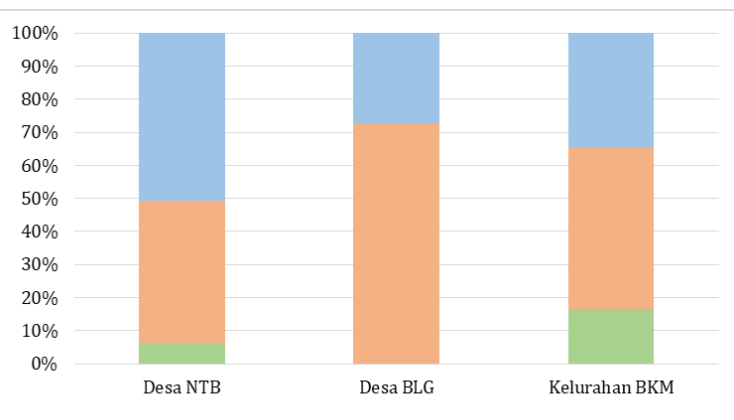

Gambar 2.Struktur Nafkah Rumah tangga Petani Kelapa Sawit Swadaya di Tiga Desa Penelitian, dalam Persentase, 2017

Dari Gambar 1 terlihat bahwa sumber nafkah rumahtangga petani sawit swadaya secara rata-rata tampak sangat beragam.Sumber nafkah yang berasal dari kelapa sawit sesungguhnya menyumbang tidak lebih dari 45 persen di semua desa yang diteliti.Artinya sekitar 55 persen sumber nafkah tidak berasal dari perkebunan kelapa sawit, melainkan dari pertanian umum dan non farm activities. Data ini menunjukkan bahwa sesungguhnya sumber nafkah dari perkebunan kelapa sawit tidak cukup signifikan untuk mengatakan bahwa tiga desa tersebut adalah sentra perkebunan sawit rakyat secara ekonomi, dimana sertifikasi ISPO dapat dengan mudah diimplementasikan.

Dengan struktur nafkah yang tidak didominasi oleh pendapatan dari kelapa sawit, maka dapat diprediksi bahwa jika sertifikasi ISPO diterapkan kepada rumahtangga petani kelapa sawit swadaya, maka biaya sertifikasi justru akan membebani sumber nafkah lainnya. Hal ini disebabkan karena proses sertfikasi ISPO membutuhkan biaya yang cukup signifikan bagi smallholders, sementara sesungguhnya struktur nafkah rumahtangga petani kelapa sawit di banyak sentra produksi masih lemah. Dengan demikian, maka rumahtangga petani kelapa sawit swadaya harus lebih intensif dalam memainkan kombinasi modal/aset yang dimiliki agar tetap dapat bertahan (Scoones, 1998).

Apabila rumahtangga petani kelapa sawit swadaya ingin memperbesar kontribusi ekonomi dari kelapa sawit, satu-satunya jalan yang dapat ditempuh oleh rumahtangga petani kelapa sawit swadaya adalah dengan melakukan ekspansi lahan (sesuatu yang akan menghasilkan resiko lingkungan hidup sangat serius). Kondisi di tiga desa lokasi penelitian mengindikasikan bahwa ketersediaan luasan lahan yang dapat diokupasi secara legal oleh petani kelapa sawit swadaya semakin sedikit jumlahnya. Rumahtangga petani kelapa sawit swadaya yang ingin melakukan ekspansi, maka hampir bisa dipastikan bahwa ekspansi yang mereka lakukan akan masuk hingga ke Kawasan Budidaya Kehutanan (KBK), yang sesungguhnya tidak diperuntukkan untuk lahan perkebunan. Dengan demikian, okupasi lahan yang dilakukan oleh rumahtangga petani kelapa sawit swadaya masuk dalam kategori ilegal. Implementasi ISPO dipastikan akan mengeksklusi lahan-lahan yang secara status peruntukan dipandang illegal.

Dua hal segera tampak dari keadaan ini: (1) kemungkinan smallholders tidak bergairah untuk mengimplementasikan ISPO karena proporsi nafkah dari kelapa sawit yang rendah; (2) Akan terjadi banyak lahan yang tereksklusi dari sertifikasi ISPO karena dipandang illegal. Pada poin kedua, hal itulah tujuan ISPO sebenarnya yaitu mengeluarkan lahan illegal dari sistem produksi legal dan berkelanjutan, agar kredibilitas pasar CPO di mata internasional dapat meningkat pada akhirnya.Resiko ini tentu berat bagi petani, oleh karenanya harus ada langkah opsional bagi peningkatan kesejahteraan.

Sebagai pengganti tindakan ekspansi (ekstensifikasi), petani kelapa sawit swadaya atau smallholders didorong untuk melakukan upaya intensifikasi lahan dimana produktivitas per hektar kebun kelapa sawit swadaya ditingkatkan (sesuai arah dari kebijakan moratorium kelapa sawit per Inpres no 8/2018). Peningkatan produktivitas ini dapat berimplikasi pada peningkatan kontribusi ekonomi dari kelapa sawit dalam struktur nafkah. Artinya, kesiapan rumahtangga petani kelapa sawit swadaya dalam melakukan sertifikasi ISPO dapat ditingkatkan hanya jika rumahtangga petani kelapa sawit swadaya mampu meningkatkan produktivitas per hektar lahan kelapa sawit yang mereka miliki, sehingga tingkat pendapatan rumah tangga meningkat.Namun demikian, faktor eksternal berupa peningkatan ataupun penurunan harga kelapa sawit dunia tetap harus menjadi perhatian, karena berpotensi menambah atau mengurangi kontribusi pendapatan rumah tangga yang berasal dari sektor kelapa sawit terhadap keseluruhan pendapatan rumah tangga.

Secara umum, ketiga desa lokasi penelitian dalam studi ini dapat mewakili karakteristik para petani kelapa sawit swadaya yang juga menghadapi kendala serupa dalam menghadapi sertifikasi ISPO. Dengan demikian, jika dilihat dari struktur nafkah rumahtangga petani kelapa sawit swadaya di tiga desa lokasi penelitian dapat disimpulkan bahwa kondisi struktur nafkah rumahtangga petani kelapa sawit swadaya saat ini sejatinya tidak dapat 
mendukung untuk dilakukannya proses sertifikasi ISPO, kecuali perbaiakn mendasar pada aspek produktivitas dilakukan terlebih dahulu. Dengan kata lain, kredibilitas CPO Indonesia di pasar internasional, tetap rendah atau gloomy sepanjang struktur nafkah sebagaimana dijelaskan di atas, terus berlangsung.

\subsection{Legalitas Lahan Kebun Kelapa Sawit Swadaya}

Standar keberlanjutan (sustainability standards) menggunakan sistem sertifikasiIndonesia Sustainable Palm Oil (ISPO) secara resmi dikeluarkan pada Maret 2011 berdasarkan pada Keputusan Menteri Pertanian Indonesia No. 19/Permentan/ OT.140/3/2011 (Obidzinski et al., 2013; Brandi et al., 2013). Salah satu prinsip yang harus dipenuhi menuju ISPO adalah legalitas lahan yang dibuktikan dengan kepemilikan sertifikat tanah, akta jual beli tanah, dan bukti kepemilikan tanah lainnya yang sah.Lahan kebun yang berada di dalam kawasan hutan, tanah negara, dan areal Hak Guna Usaha (HGU) tidak bisa memiliki bukti kepemilikan tanah yang sah.Tanah dengan klaim yang umpang tindih dipandang tanah bermasalah yang harus dikeluarkan dari ISPO.

Secara ideal, skema sertifikasi ISPO merencanakan agar seluruh petani kelapa sawit swadaya di Indonesia dapat tersertifikasi (Brandi et al., 2013).Untuk menuju ke arah sertifikasi ISPO, perlu dilihat kembali tentang penggunaan lahan untuk kebun sawit di Indonesia terutama bagi petani kelapa sawit swadaya.Studi kelak menyimpulkan bahwa tidak semua lahan petani bisa diikutsertakan dalam sertifikasi ISPO, karena asal-usulnya yang tidak jelas secara hukum.

Studi yang dilakukan di tiga lokasi ini telah mewakili sebagian besar desa-desa di Indonesia yang di dalamnya terdapat perkebunan kelapa sawit swadaya.Rata-rata luas lahan perkebunan kelapa sawit swadaya berkisar antara 2-6 Ha per rumahtangga petani.Sebagian besar perkebunan kelapa sawit swadaya dikembangkan di dua tipe status legal tanah yang ada di pedesaan.Status pertama adalah perkebunan kelapa sawit yang dikembangkan di Kawasan Budidaya Non Kehutanan (KBNK) atau Area Penggunaan Lain (APL).Pada status pertama ini, penanaman kelapa sawit dinyatakan sah secara undang-undang kehutanan dan karenanya sesuai dengan prinsip-prinsip keberlanjutan dalam praktik perkebunan.Status kedua adalah perkebunan kelapa sawit yang dikembangkan di Kawasan Budidaya Kehutanan (KBK).Kelapa sawit yang ditanam di atas lahan degan status seperti ini dinyatakan tidak sah secara undang-undang kehutanan dan tidak memenuhi prinsip-prinsip keberlanjutan dalam budidaya perkebunan.Lahan perkebunan di kawasan KBK inilah yang saat ini menjadi pokok persoalan penolakan produk sawit Indonesia di negara-negara Uni Eropa.

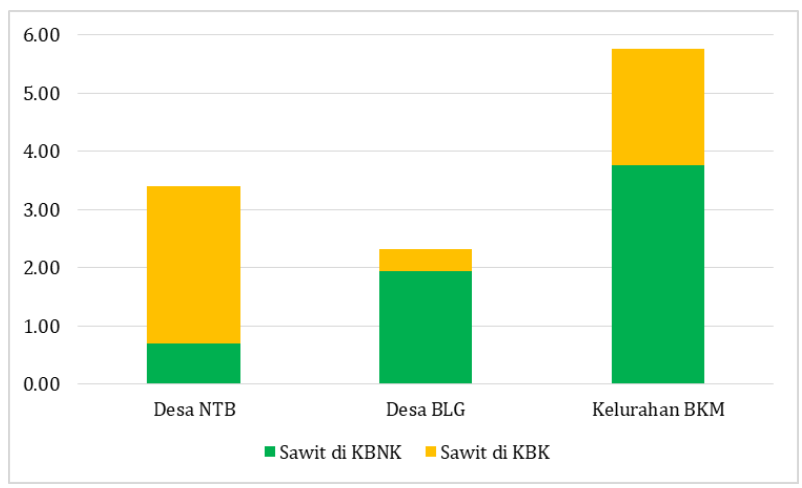

Gambar 3. Luas Penguasaan Rata-rata Rumahtangga Petani Kelapa Sawit Swadaya di Tiga Desa Penelitian, berdasarkan Letak/Status Legalnya, dalam Satuan Hektar (Ha)

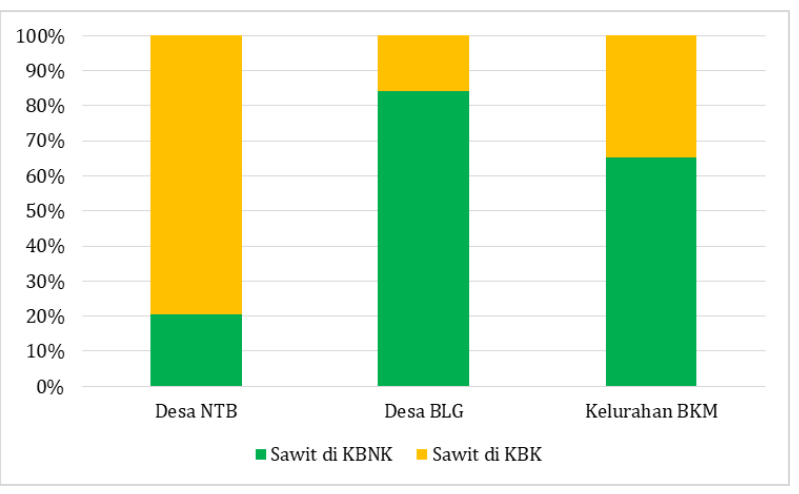

Gambar 4.Luas Penguasaan Rata-rata Rumahtangga Petani Kelapa Sawit Swadaya di Tiga Desa Penelitian, berdasarkan Letak/Status Legalnya,dalam Persentase, 2017

Pada Gambar 3 dan 4diperlihatkan bahwa struktur agraria perkebunan kelapa sawit yang illegal (kelapa sawit di dalam Kawasan Budidaya Kehutanan/KBK) di Desa NTB (Provinsi Kalimantan Tengah) lebih tampak dominan dibandingkan lahan perkebunan kelapa sawit di tanah yang legal (kelapa sawit di dalamKawasan Budidaya Non Kehutanan/KBNK).Sementara itu struktur agraria perkebunan di Desa BLG (Provinsi Riau) dan Kelurahan BKM (Provinsi Kalimantan Timur) lebih didominasi oleh perkebunan sawit di lahan yang legal (KBNK). Sekalipun demikian, Gambar 3 dan 4 menunjukkan bahwa perkebunan kelapa sawit swadaya/rakyat di tiga desa penelitian, seluruhnya terlibat dalam isu ekspansi lahan perkebunan ke kawasan budidaya kehutanan (KBK) yang menyebabkannya, mereka dilabel sebagai desa-desa dengan insiden illegalitas tanah yangmenonjol.

Gambar 3 dan 4dalam hal ini menunjukkan bahwa seluruh desa yang diteliti tidak terbebas dari fenomena ekspansi perkebunan sawit illegal.Fakta ini menunjukkan juga konsekuensi bahwa semua produksi kelapa sawit yang berasal dari tiga desa tersebut beresiko terhadap konflik agraria, pemburukan kualitas lingkungan hidup dan ketidakberlanjutan sehingga tidak dapat disertifikasi oleh ISPO.Status illegal land biasanya disebabkan 
karena perkebunan kelapa sawit yang diusahakan berada di kawasan konservasi (forest conservation land) atau kawasan hutan produksi.Status illegal land biasanya berkaitan dengan pola ekspansi perkebunan kelapa sawit yang dilakukan oleh petani kelapa sawit swadaya karena tidak tersedianya lagi lahan di kawasan APL/KBNK yang tersisa.Struktur agraria perkebunan kelapa sawit seperti ini (illegal land) yang kemudian memberikan konsekuensi negatif terhadap kredibilitas komoditas kelapa sawit Indonesia di pasar internasional atau di mata dunia secara umum. Secara prinsip tata tata kelola perkebunan, setiap CPO atau produk kelapa sawit yang berasal dari illegal land dinyatakan tidak berkelanjutan karena terikat pada persoalan resiko lingkungan berupa deforestasi, degradasi hutan, dan seringkali juga dianggapviolenceterhadap masyarakat adat di dalam hutan (Dauvergne, 2018). Selain itu, hal ini telah melanggar prinsip-prinsip good agricultural governance.

Kasus-kasus legalitas lahan untuk perkebunan kelapa sawit di Indonesia (legal dan illegal) biasanya muncul di beberapa desa yang terletak di sekitar kawasan hutan lindung atau kawasan konservasi.Ekspansi perkebunan kelapa sawit swadaya ke dalam kawasan hutan biasanya terjadi semakin massif manakala harga CPO di dunia meningkat.Namun demikian, ada factor internal yang berpengaruh.Beberapa sebab petani kelapa sawit swadaya terus berekspansi ke dalam kawasan hutan adalah: a) pengawasan terhadap kawasan hutan sangat lemah dan tidak tegas, bahkan kompleksitas teknis dari prosedur formal untuk konversi hutan menjadi kelapa sawit terkadang sangat mudah dilewati (Setiawan et al., 2016). Kemudahan ini terkait dengan niat(desire) dari pemerintah lokal dalam menggunakan forest land untuk menaikkan ekonomi lokal (Setiawan et al., 2016); b) petani kebun kelapa sawit swadaya menghadapi ketidakpastian tata batas antara kawasan hutan dengan APL; c) lahan APL terbatas untuk perkebunan kelapa sawit dan perlu biaya biaya besar untuk memiliki lahan di APL (Brandi et al., 2013). Alasan petani sawit terus melakukan ekspansi adalah dorongan permintaan minyak sawit dunia yang cukup tinggi dimana mereka melihat ada keuntungan besar di sana. Paradoks Jevons menyatakan bahwa peningkatan permintaan seperti itu dapat berfungsi sebagai insentif atau pendorong petani untuk memperluas area lahan hingga ke kawasan yang sejatinya tak boleh diokupasi (Varkkey et al., 2018).

Persoalan land encroachment ke dalam kawasan hutan yang dilakukan oleh rumahtangga petani kelapa sawit swadaya (smallholders)seringkali juga disebabkan oleh sejarah agraria yang panjang dan kompleks. Pada masa awal okupasi lahan petani di dalam kawasan hutan biasanya didasarkan pada legitimasi adat.Pada masa awal tersebut, kawasan yang telah berubah menjadi kebun kelapa sawit tersebut sejatinya masih tanah adat yang setara dengan KBNK.Pada tahun berikutnya, manakala Pemerintah mencanangkan kawasan tersebut sebagai KBK, melalui peraturan yang sepihak, maka tiba-tiba kebun petani berada di kawasan yang tidak sah.Sebagai akibatnya, kebun kelapa sawit yang telah lama berada di dalam kawasan, secara tiba-tiba dinyatakan sebagai kebun sawit yang illegal.

Dengan struktur agraria perkebunan yang seperti ini maka kesiapan rumahtangga petani untuk terlibat dalam sertifikasi ISPO terutama syarat untuk memenuhi kriteria legalitas lahan menjadi lemah.Artinya sertifikasi ISPO menjadi sangat sulit untuk diterapkan pada rumahtangga petani kelapa sawit swadaya yang memiliki kebun ganda di kawasan legal dan illegal.

Legalitas lahan juga ditunjukkan melalui kepemilikan sertifikat tanah. Studi Brandi et al., 2013 menunjukkan bahwa teridentifikasi bahwa terdapat gap antara persyaratan standar sertifikasi RSPO dengan praktik di lapangan, salah satunya adalah keberadaan sertifikat tanah yang sulit diadakan oleh petani. Fakta lapangan pada studi ini juga menunjukkan bahwa sertifikat tanah sebagai salah satu syarat dalam sertifikasi ISPO sepenuhnya belum terpenuhi. Sebagian besar petani kelapa sawti swadaya di tiga lokasi studi tidak memiliki sertifikat tanah melainkan hanya sebatas Surat Keterangan Tanah (SKT) atau Surat Keterangan Ganti Rugi (SKGR) yang dikeluarkan oleh badan berwenang pada level kecamatan dan desa.Baik SKT maupun SKGR bukan alas hakatas penguasaan lahan yang kuat dan sah di mata hukum formal.

\subsection{Legalitas Bibit Kebun Kelapa Sawit Swadaya}

Menelusuri asal usul atau sumber kelapa sawit adalah hal yang sulit dilakukan bahkan dengan konsentrasi tinggi dalam produksi sawit dunia di Indonesia dan Malaysia (Dauvergne, 2018).Dengan demikian, skema RSPO (Roundtable for Sustainable Palm Oil) muncul sebagai inisitatif sukarela dari multi pihak yang berfungsi untuk mengatur rantai pasokan minyak sawit demi mendorong pertumbuhan dan penggunaan minyak sawit berkelanjutan melalui standar global yang kredibel (Brandi et al., 2013). Namun untuk mempermudah jalannya perkebunan kelapa sawit yang berkelanjutan, pemerintah Indonesia memunculkan ISPO yang berfungsi sebagai wahana untuk meningkatkan hasil produksi dan kualitas minyak sawit Indonesia dengan memperkuat aturan yang ada, sehingga selaras dengan tuntutan pembangunan yang berkelanjutan (Brandi et al., 2013).

Selain legalitas lahan, salah satu prinsip atau kriteria ISPO lainnya adalah tentang legalitas bibit yang ditandai dengan bibit kelapa sawit bersertifikat.Fakta di lapangan menunjukkan bahwa rumahtangga petani kelapa sawit swadaya membeli bibit kelapa sawit yang tidak bersertifikat.Asal usul bibit kelapa sawit yang ditanam adalah dari petani sawit lainnya yang bibitnya belum jelas legalitasnya, atau bibit kelapa sawit yang mereka gunakan adalah hasil pembibitan secara mandiri oleh para petani itu sendiri.Hal ini dinilai sebagai bibit yang tidak sah, karena boleh jadi ada resiko atas penggunaan plasma 
nutfah yang tidak dapat dipertanggungjawabkan dampaknya di kemudian hari.

Pada tiga lokasi studi yang diteliti telah mewakili karakteristik petani kelapa sawit swadaya di Indonesia dalam memanfaatkanbibit di kebunnya.Karakteristik tersebut adalah bahwa persentase penggunaan bibit kelapa sawit bersertifikat biasanya tidak lebih dari $40 \%$ dari luas kawasan kebun kelapa sawit yang ada. Dalam hal ini, bibit bersertifikat pada kebun sawit swadaya hanya $14,71 \%$ di Desa BLG (Riau), 17,65\% di Desa NTB (Kalimantan Tengah), dan 38,24\% di Kelurahan BKM (Kalimantan Timur). Artinya sebagian besar kebun kelapa sawit yang ada tidak menggunakan bibit bersertifikat, walaupun dalam beberapa kasus di dalam satu persil kebun kelapa sawit terdapat pohon sawit yang sebagian bersertifikat dan sebagian lainnya tidak bersertifikat.Dari perspektif penggunaan bibit, dapat dikatakan bahwa sebagian besar lahan kebun petani kelapa sawit swadaya atau smallholders tidak memenuhi syarat ISPO.

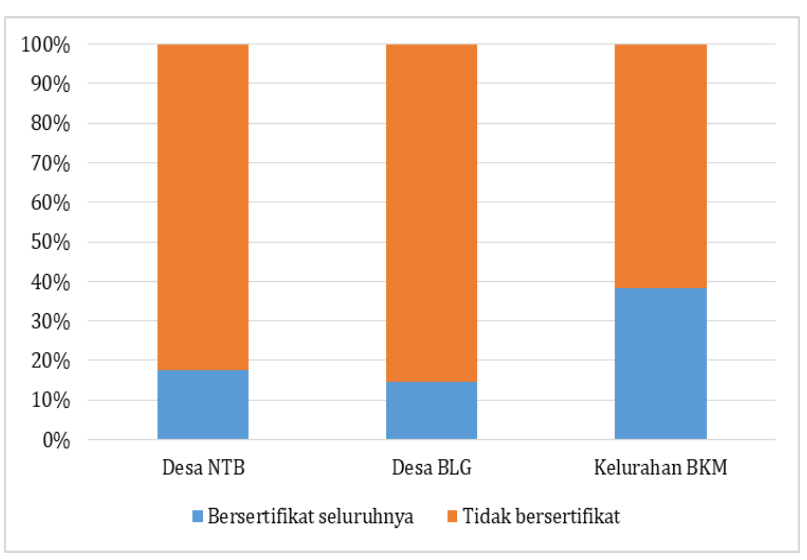

Gambar 5. Status Legalitas Bibit Kelapa Sawit di Tiga Desa Penelitian dalam persentase, 2017

Gambar 5 menunjukkan bahwa sebagian besar bibit kelapa sawit di tiga desa penelitian adalah illegal (dari kacamata ISPO), karena bibit yang digunakan bukan berasal dari lembaga yang berwenang untuk mengeluarkan bibit bersertifikat.Pada kisaran 62\% - 86\% lahan kelapa sawit smallholders menggunakan bibit kelapa sawit yang dinyatakan illegal dan menyebabkan kelapa sawit swadaya akan kesulitan mengikuti sertifikasi ISPO kecuali dengan resiko yang sangat besar dan sulit untuk dilakukan yaitu dengan membongkar kebun dan menggantinya dengan bibit bersertifikat.Melakukan pembongkaran kebun, beresiko pada biaya investasi yang sangat besar dan seringkali di luar kemampuan petani.Selain itu, bibit bersertifikat dipandang mahal dan sulit diadakan, sehingga sebagian besar petani sampel bergantung pada sumber bibit yang diragukan.Pada umumnya pembelian bibit dilakukan ke tetangga atau tempat pembibitan pribadi yang asal usul benih tidak diketahui dengan pasti (Brandi et al., 2013).
Salah satu hal penting dalam sertifikasi ISPO adalah prinsip legalitas bibit atau bibit kelapa sawit bersertifikat untuk memenuhi standar tata kelola lingkungan hidup dan sumberdaya alam yang lestari.Bila prinsip legalitas bibit ini tidak terpenuhi, maka keseluruhan prinsip tidak berlaku bagi petani yang bersangkutan.Artinya setiap persil kebun yang di dalamnya tumbuh pohon kelapa sawit dengan bibit tidak bersertifikat, maka kebun tersebut dianggapillegal dari perspektif budidaya perkebunan yang berkelanjutan (ISPO). Melihat pada fakta bahwa di tiga lokasi studi tersebut menampilkan bibit kelapa sawit tanpa sertifikat yang dominan, maka dapat disimpulkan bahwa: a) sebagian besar petani kelapa sawit swadaya dapat dikatakan sebagai tidaktaat pada prinsip tata kelola kelapa sawit yang berkelanjutan; b) oleh karena itu, petani sawit swadaya tersebut tidak akan bisa mengimplementasikan sertifikasi ISPO. Berdasarkan fakta ini menunjukkan bahwa kebun kelapa sawit swadaya tidak siap untuk menjalankan sertifikasi ISPO. Dengan kata lain, tata kelola kebun kelapa sawit swadaya mengalami kendala keberlanjutan dalam hal asal usul bibit. Ujung dari persoalan ini sama, yaitu setiap produk yang dihasilkan oleh kebun kelapa sawit dari tanaman yang bibitnya dipandang illegal, maka akan ditolak oleh pasar internasional.

\subsection{Pengelolaan Lingkungan Hidup Kebun Kelapa Sawit Swadaya}

Aktivitas pembangunan yang dilakukan dalam berbagai bentuk usaha dan/atau kegiatan pada dasarnya akan menimbulkan dampak atau resiko terhadap lingkungan. Dampak yang ditimbulkan dianalisis sejak awal perencanaan sehingga langkah pengendalian dampak negatif dan pengembangan dampak positif dapat disiapkan sedini mungkin. Pasal 22 Undang-Undang Nomor 32 Tahun 2009 tentang Perlindungan dan Pengelolaan Lingkungan Hidup dan pasal 3 Peraturan Pemerintah No.27 Tahun 2012 tentang Izin Lingkungan menetapkan bahwa setiap usaha dan/atau kegiatan yang berdampak penting wajib memiliki AMDAL (untuk skala besar) atau UKL-UPL bagi usaha skala kecil termasuk perkebunan.

Dari Gambar 6 terlihat bahwa keragaman tingkat pengetahuan yang dimiliki oleh para petani kelapa sawit swadaya terhadap prinsip-prinsip ISPO, utamanya terkait dengan pengelolaan lingkungan hidup. Dalam hal pengelolaan dan pemantauan lingkungan kebun kelapa sawit swadaya di ketiga desa, pembukaan kebun kelapa sawit oleh petani kelapa sawit swadaya dengan cara pembakaran, memang telah lama ditinggalkan. Mereka memahami bahwa tindakan tersebut merusak lingkungan dan melanggar peraturan yang ada dan ditetapkan oleh pemerintah.Meskipun demikian, atas pertimbangan efisiensi (ekonomi), masih ada segelintir petani kelapa sawit swadaya yang membuka lahan untuk kelapa sawit dengan melakukan pembakaran bekerjasama dengan warga komunitas 
lainnya.Artinya, emisi karbon, tetap menjadi potensi ancaman sekalipun tidak lagi besar skalanya.

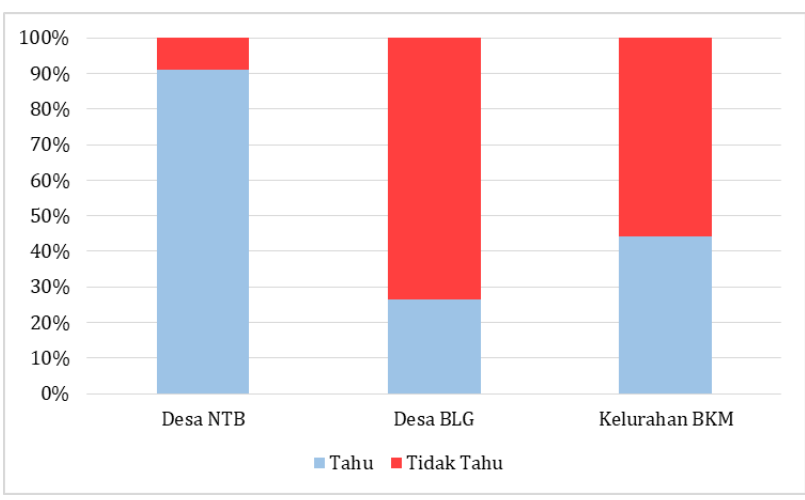

Gambar 6. Pengetahuan Petani Kelapa Sawit Swadaya tentang Sertifikasi ISPO di Tiga Desa Penelitian dalam persentase, 2017

Dalam hal pengelolaan kawasan, tampak hal menarik bahwa secara sosio-ekologis perkebunan kelapa sawit di salah satu desa studi misalnya, adalah semakin banyaknya anak-anak sungai di sekitar kebun yang hilang, dan banyaknya jenis hewan yang hilang, serta pohon-pohon kayu besar sudah tidak ada lagi (langka), dismaping kebun karet semakin berkurang.Semua ini terjadi dikarenakan, konversi lahan hutan yang perhitungan. Selain itu juga berpengaruh terhadap debit dan kualitas air untuk kebutuhan rumahtangga sehari-hari. Kegiatan pemeliharaan tanamanan yang menggunakan bahan kimia dengan tujuan untuk meningkatkan kualitas tanaman juga memiliki resiko yakni turut berkontribusi dalam penurunan kualitas lingkungan.Data dari lapangan menunjukkan bahwa aplikasi pestisida terhadap perkebunan kelapa sawit swadaya bervariasi dosis/takarannya dan cenderung tidak sesuai dengan anjuran serta masih dalam batas yang lebih rendah dari standar yang telah ditetapkan.Akan tetapi penggunaan pestisida tetap beresiko menjadi penyebab kerusakan lingkungan hidup di ekosistem setempat.Sementara penggunaan pupuk organic yang ramah lingkungan, bagi kebun kelapa sawit swadaya masih belum diterapkan secara intensif ataupun meluas dan masih bersifat sukarela penerapannya.

Petani kelapa sawit swadaya umumnya tidak memiliki Surat Tanda Daftar Budidaya (STD-B) yang disyaratkan dalam ISPO dan juga tidak memiliki Dokumen Rencana Operasional Budidaya.Menurut persepsi para petani, pengelolaan dan pemantauan lingkungan belum maksimal karena masih sedikitnya imformasi resmi dari pemerintah yang mereka terima melalui kegiatan sosialisasi ataupun penyuluhan. Sosialisasi yang dimaksud antara lain adalah sosialisasi Pembukaan Lahan Tanpa Bakar (PLTB) dan dampak (sosial-ekonomi-ekologi) dari kegiatan berkebun yang tidak sesuai dengan prosedur.
Kegiatan pencegahan kebakaran dirasakan kurang penting karena di tiga desa lokasi penelitian hampir tidak pernah terjadi kebakaran lahan, utamanya lahan kebun kelapa sawit.Kenyataannya, beberapa jenis tanaman tidak banyak lagi ditemukan sebagai konsekuensi ekspansi perkebunan kelapa sawit yang monokultur sifatnya. Beberapa spesies hewan dengan sengaja dimusnahkan karena dianggap sebagai hama dan mengganggu tanaman kelapa sawit milik masyarakat. Ketidaktahuan ini membuat sebagian besar petani kelapa sawit swadaya beranggapan bahwa pengelolaan lingkungan yang baik dan benar bukan merupakan sesuatu yang mendesak dan menjadi prasyarat bagi keberlangsungan usaha kebun kelapa sawit yang mereka miliki. Tampaknya, katakunci dalam hal ini adalah proses komunikasi dan arus informasi yang belum memadai antara pemerintah dengan petani kelapa sawit swadaya dan sebaliknya.

Dengan demikian, jika dilihat dari rendahnya pengetahuan petani kelapa sawit swadaya mengenai pentingnya pengelolaan lingkungan hidup yang baik dan benar di ketiga desa lokasi penelitian dapat disimpulkan bahwa petani kelapa sawit swadaya di Desa NTB, BLG dan Kelurahan BKM saat ini belum siap untuk sepenuhnya melaksanakan proses sertifikasi ISPO.Upaya pemerintah untuk membantusmallholders agar dapat menguatkan prinsip pengelolaan sumberdaya alam dan lingkungan secara memadai, sangat krusial dan kritikal.

\subsection{Analisis Gapuntuk Implementasi ISPO}

Untuk membantu petani kelapa sawit swadaya atau smallholders agar mampu mendekati implementasi sertifikasi ISPO, maka studi di tiga desa ini mencoba untuk melakukan analisis gap. Jurang perbedaan diberlakukan dalam melihat beberapa prinsip sertifikasi ISPO dari pandangan petani. Studi melihat perbedaan antara what is (apa yang terjadi) dan what should (apa yang seharusnya terjadi) pada petani terkait empat prinsip ISPO bagi smallholders beserta indikator-indikator turunannya. Hasil analisis ditampilkan pada Gambar 7.

Terdapat 7 prinsip yang dapat digunakan untuk mengkaji kesiapan petani dalam menerapkan sertifikasi ISPO secara keseluruhan yakni 1) Kepatuhan dengan peraturan perizinan hukum, 2) Tanggung jawab untuk menerapkan manajemen perkebunan kelapa sawit, 3) Pelaksanaan praktik terbaik di perkebunan dan pabrik kelapa sawit, 4) Tanggung jawab untuk menerapkan peraturan tentang lingkungan dan konservasi sumber daya alam, 5) Tanggung jawab terhadap karyawan, 6) Tanggung jawab kepada individu yang terkena dampak perkebunan kelapa sawit dan pabrik, dan 7) Komitmen jangka panjang untuk meningkatkan ekonomi. Sementara dalam penelitian ini hanya 4 prinsip yang dikaji yakni 1) legalitas lahan dan kebun swadaya, 2) Organisasi pekebun dan pengelolaan kebun swadaya, 3) Pengelolaan dan pemantauan 
lingkungan kebun swadaya, dan 4) Peningkatan usaha berkelanjutan.
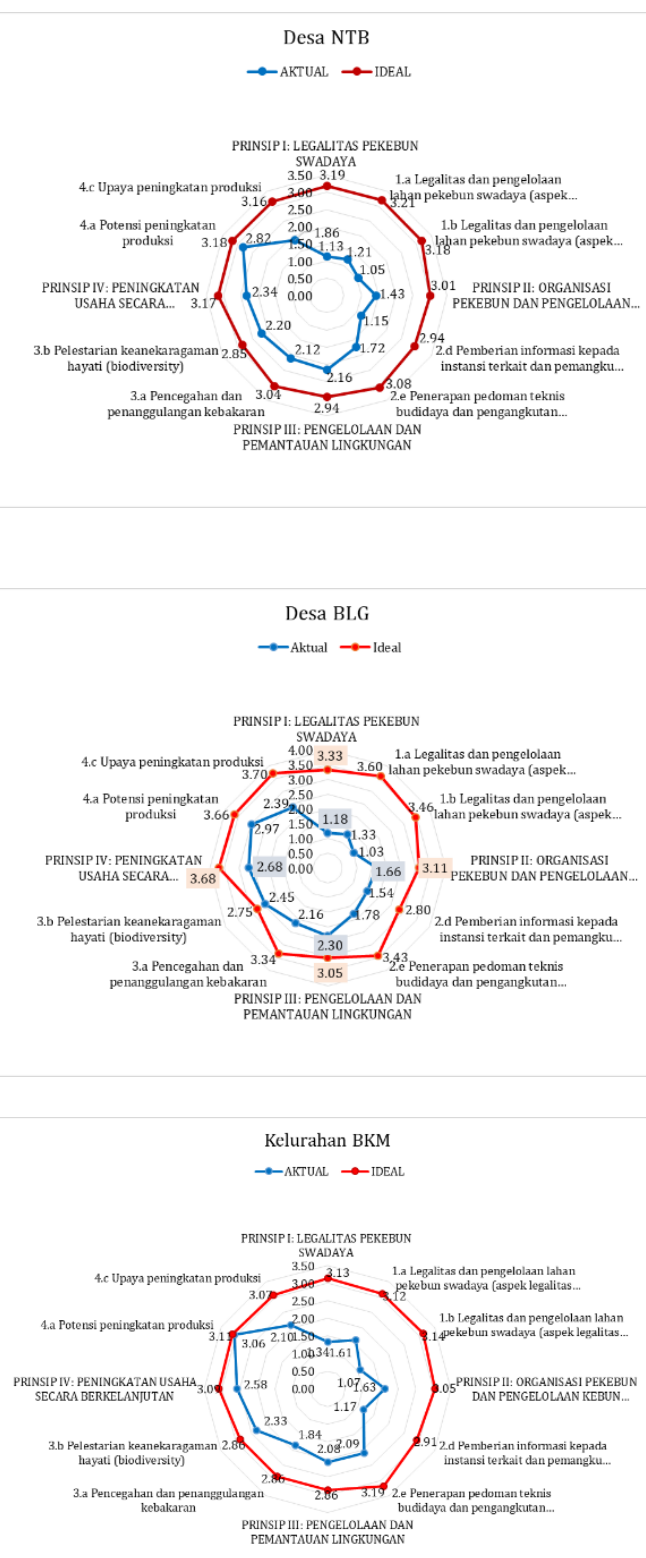

Gambar 7.Analisis Kesenjangan (Gap Analysis) pada Empat Prinsip Sertifikasi ISPO untuk Petani Kelapa Sawit Swadaya di Tiga Desa Penelitian, 2017

Dalam hal ini, keempat prinsip tersebut dipecah ke dalam 8 (delapan) indikator yang dibahas secara lebih rinci, yakni legalitas lahan, legalitas usaha, keterdedahan terhadap informasi mengenai ISPO, informasi mengenai teknik budidaya pertanian yang baik, manajemen resiko terhadap kebakaran lahan, pengetahuan petani mengenai biodiversitas, peningkatan produksi, dan peningkatan usaha.

Data yang diperoleh di ketiga desa lokasi penelitian menunjukkan bahwa terjadi kesenjangan (gap) yang sangat signifikan antara kondisi ideal (harapan - what should) dengan kondisi riil (what is)padapetani di lapangan. Gap antara what is dan what should ini menjelaskangap kesiapan (readiness) petani kelapa sawit swadaya untuk dalam menerapkan keseluruhan prinsip sertifikasi ISPO. Dari Gambar 6 terlihat pula bahwa gap(diperlihatkan oleh jarak antara titik merah dan titik biru pada setiap inidikator ISPO) terjadi di semua desa yang diteliti. Namun gap yang relatif paling besar terjadi di Desa NTB, Provinsi Kalimantan Tengah. Fakta terjadinya gap ini, menjelaskan banyak hal, bahwa: a) Sejatinya kesiapan petani kelapa sawit swadaya atau smallholders masih sangat lebar untuk mengikuti sertifikasi ISPO; b) ihwal keberlanjutan (sustainability) yang menjadi tuntutan seturut perspektif ISPO bagi kebanyakan petani kelapa sawit rakyat adalah sesuatu yang sulit dipenuhi; c) petani kelapa sawit swadaya/rakyat (smallholders) masih memerlukan bantuan dari pemerintah untuk mempersempit gap pada indikator-indikator ISPO, bila perkebunan kelapa sawit berkelanjutan (sustainable oil palm) ingin dicapai.

\section{Kesimpulan}

Dengan melihat pada kesiapan petani kelapa sawit swadaya di tiga lokasi penelitian dalam menghadapi implementasi ISPO, secara struktur nafkah dinyatakan tidak siap karena pendapatan dari oil palm bukan merupakan sumber nafkahyang utama atau dominan. Dari sisi legalitas lahan juga tidak siap karena kebanyakan kebun menghadapi persoalan legalitas lahan (ketiadaan alas legal berupa sertifikat tanah)dimana konflik agraria antara kebun dan kawasan lindung tampak muncul di semua desa kasus. Dari sisi legalitas bibit juga dinyatakan tidak siap untuk mengimplementasikan ISPO karena sebagian besar petani kelapa sawit swadaya menggunakan bibit yang tidak jelas asal-usulnya.Jika sekalipun dinyatakanbersertifikat, tetapi bibit tersebut teridentifikasi bukan berasal dari lembaga yang berwenang untuk mengeluarkan sertifikat bibit.Dari legalitas pengelolaan lingkungan hidup juga dinyatakan tidak siap karena sebagian besar petani tidak mengetahui prinsip-prinsip pengelolaan lingkungan sesuai dengan standar ISPO yang ideal.

Melihat pada ketidaksiapan petani kelapa sawit swadaya dalam menghadapi implementasi ISPO maka rekomendasi yang diajukan antara lain: a) untuk mengimplementasikan sertifikasi ISPO terhadap petani kelapa sawit swadaya hanya bisa dilakukan dengan resiko yang sangat besar yaitu resiko ekonomi berupa pembongkaran kebun dan reinvestasi kebun sawit; b) diperlukan proses legalisasi lahan dan administrasi yang terkait dengan persoalan lahan yang cukup kompleks dan berbelibelit di tingkat desa hingga level supra desa; dan c) diperlukan proses pendampingan yang sangat intensif untuk memberikan tidak hanya kesadaran pengetahun tentang prinsip-prinsip keberlanjutan dan sertifikasi namun juga proses pendampingan kepada petani untuk membantu sertifikasi dan meyakinkan stakeholders terkait (misalnya pabrik).Hal terakhir, yang disarankan adalah pemangku otoritas perkebunan kelapa sawit, perlu membantu petani kelapa sawit swadaya dengan 
berbagai upaya untuk mempersempit gap berbagai indikator sertifikasi ISPO.Petani memahami persoalan yang dihadapi dalam upaya mencapai oil palm sustainability, namun mereka tidak berdaya untuk mengatasi masalah yang dihadapinya tanpa bantuan pihak eksternal (pemerintah).

Acknowledgement: Tulisan ini diekstrak dari hasil studi besar dengan tema Revamping ISPO yang dilakukan oleh tim peneliti dari Pusat Studi Pembangunan Pertanian dan Pedesaan IPB di lima Provinsi di Indonesia sepanjang 2017-2018, dengan dukungan pendanaan dari Yayasan Kehati, Jakarta. Para peneliti/penulis berterima kasih kepada Yayasan Kehati, atas dukungan dana pada penelitian tersebut. Tanggung jawab tulisan ini tetap berada pada tim penulis.

\section{DAFTAR PUSTAKA}

Abram NK, Meijaard E, Wilson KA, DavisJT, Wells JA, Ancrenaz M, Budiharta S, Durrant A,Fakhruzzi A, Runting RK, Gaveau D, Mengersen K. 2017. Oil palm-community conflict mapping in Indonesia: A case forbetter community liaison in planning fordevelopment initiatives. Applied Geography.Vol.

78.https://doi.org/10.1016/j.apgeog.2016.10.00 5.Hal.33-44.

BPS Kabupaten Kotawaringin Timur.2017. Kecamatan Mentaya Hilir Utara dalam Angka 2017.Kabupaten Kotawaringin Timur: BPS Kabupaten Kotawaringin Timur.

BPS Kabupaten Pelalawan.2017. Kecamatan Bunut dalam Angka 2017. Kabupaten Pelalawan: BPS Kabupaten Pelalawan.

Brandi, Clara, Tobias C, Christoph H, Sonja S, Lotte W, Hannah W. 2013. Sustainability certification in the Indonesian palm oil sector: benefits and challenges for smallholders. Bonn: German Development Institute.

Dauvergne P. 2018. The global politics of the business of "sustainable" palm oil. Global environmental politics. 18:2, May 2018, doi: 10.1162/glep_a_00455.

Direktorat Jenderal Perkebunan. 2015. Statistik Perkebunan Indonesia.Kelapa Sawit 2015-2017. Kementerian Pertanian. Jakarta.

Direktorat Jenderal Perkebunan Kementerian Pertanian. 2016. Statistik Perkenunan Indonesia Tahun 2015-2017 Kelapa Sawit.

Ellis F. 2000. Rural Livelihood and Diversity in Development Countries: Evidence and Policy Implications. New York (US): Oxford University Press.

Euler M, Krishna V, Schwarze S, Siregar H, Qaim M. 2017.0il palm adoption, household welfare, and nutrition among smallholder farmers in Indonesia.World Development.http://dx.doi.org/10.1016/j.worldd ev.2016.12.019.

Gatto M, Wollni M, Qaim M. 2015. Oil palm boom and landuse dynamics in Indonesia: The role of policies and socioeconomic factors. Land Use Policy. http://dx.doi.org/10.1016/j.landusepol.2015.03.0 01. Hal: 292-303.
Gaveau DLA, Sheil D, Husnayaen SMA, Arjasakusuma S, Accrenaz M, Pacheco P, Meijaard E. 2016. Rapid conservations and avoided deforestation: examining four decades of industrial plantation expansion in Borneo. Sci. Rep 6, 32017.(Accessed 8 October 2018).

Greenpeace International. 2010. Protection Money. Synchronicity Earth.

Hansen SB, Padfield R, Syayuti K, Evers S, Zakariah Z, Mastura S. 2015. Trends in global palm oil sustainability research.Journal of Cleaner Production.doi: 10.1016/j.jclepro.2015.03.051.

Jelsma I, Schoneveld GC, Zoomers A, Westen ACMv. 2017. Unpacking Indonesia's independent oil palm smallholders:An actor-disaggregated approach to identifying emvironmental and social performance challenges. Land Use Policy. Vol. 69.https://doi.org/10.1016/j.landusepol.2017.08. 012. Hal: 281-297.

Kelurahan Bukit Merdeka. 2017. Potensi Kelurahan Bukit Merdeka 2017. Kantor Kelurahan Bukit Merdeka (unpublished).

Mantra IB, Kasto. 1989. Penentuan Sampel. Di dalam: Singarimbun M dan Effendi S, editor. Metode Penelitian Survai. Jakarta (ID): Pustaka LP3ES Indonesia,anggota IKAPI.

Khatun R, Reza MIH, Moniruzzaman M, Yaakob Z. 2017. Sustainable oil palm industry: The possibilities. Renewable and Sustainable Energy Reviews.Vol. 76.https://doi.org/10.1016/j.rser.2017.03.077. Hal: 608-619.

Obidzinski K, Andriani R, Komarudin H, Andrianto A. 2012. Environmental and social impacts of oil palm plantations and their implications for biofuel production in Indonesia. Ecology and Society.http://dx.doi.org/10.5751/ES-04775170125 .

Obidzinski K, Takahashi I, Dermawan A, Komarudin H, Andrinato A. 2013. Can large scale land acquisition for agro-development in Indonesia be managed sustainably?.Land Use Policy. http://dx.doi.org/10.1016/j.landusepol.2012.06. 018. Hal:

Ocampu-Penuela N, Garcia-Ulloa J, Ghazoul J, Etter A. 2018.Quantifying impacts of oil palm expansion on Colombia's threatened biodiversity.Biological Conservation.https://doi.org/10.1016/j.biocon.20 18.05.024. Hal: 117-121.

Pacheco P, Schoneveld G, Dermawan A, Komarudin H, Djama M. 2018. Governing sustainable palm oil supply: Disconnects, complementarities, and antagonisms between state regulations and private standards. Regulation and Governance. doi:10.1111/rego.12220.

Pearce F. 2017. Can a deforestation driver become a forest protector? Colombo Sri Lanka: Tge CGIAR Research Program on Water, Land and Ecosystems (WLE). https://wle.cgiar.org/thrive/2017/01/16/candeforestation-driver-become-forestprotector?utm_content=bufferc0ea0\%0B\&\%0But m_medium=social $\% 0 \mathrm{~B} \& \% 0 \mathrm{Butm} \_$source $=$twitter. com\%0B\&\%0Butm_campaign=buffer (Accessed 8 October 2018).

Pierre J. 2000. Debating Governance: Authority, Steering, and Democracy. Oxford University Press.

Purnomo H, Okarda B, Dewayani AA, Ali M, Achdiawan R, Kartodiharjo H, Pacheco P, Juniwaty KS. 2017. 
Reducing forest and land fires through good palm oil value chain governance. Forest Policy and Economic.https://doi.org/10.1016/j.forpol.2017. 12.014.

Pusat Data dan Sistem Informasi Pertanian Sekretariat Jenderal Kementerian Pertanian. 2016. Outlook Kelapa Sawit Komoditas Pertanian Subsektor Perkebunan.

Saadun N, Lim EAL, Esa SM, Ngu F, Awang F, Gimin A, Johari IH, Firdaus MA, Wagimin NI, Azhar B. 2018. Socioecological perspectives of engaging smallholders in environmental-friendly palm oil certification schemes. Land Use Policy. https://doi.org/10.1016/j.landusepol.2017.12.05 7.Hal: 333-340.

Scherr JS, White A, Kaimowitz D. 2004. A New Agenda for Forest Conservation andPoverty Reduction: Making Markets Work for Low-income Producers. Forest Trend, Washington.

Schouten G, Glasbergen P. 2011. Creating legitimacy in global private governance: The case of the Rountable on Sustainable Palm Oil.Ecological Economics.doi:10.1016/j.ecolecon.2011.03.012.H al: 1891-1899.

Scriven SA, Gillespie GR, Laimun S, Goossens B. 2018. Edge effects of oilpalm plantations on tropical anuran communities in Borneo.Biological Conservation.Vol 220.https://doi.org/10.1016/j.biocon.2018.02.00 6. Hal: 37-49.
Scoones I. 1998.Sustainable Rural Livelihood A Framework for Analysis.IDS Working Paper: 72.

Setiawan EN, Maryudi A, Purwanto RH, Lele G. Opposing interests in the legalization of non-procedural forest conversion to oil palm in Central Kalimantan, Indonesia. Land use policy. http://dx.doi.org/10.1016/j.landusepol.2016.08.0 03. Hal: 472-481.

Silalertruksa T, Gheewala SH, Pongpat P, Kaenchan P, Permpool N, Lecksiwilai N, Mungkung R. 2017. Environmental sustainability of oil palm cultivation in different regions of Thailand: greenhouse gases and water use impact. Journal of Cleaner Production. Hal: 1009-1019.

Teoh Cheng Hai. 2010. Key Sustainability Issues in the Palm Oil Sector. International Finance Corporation, World Bank Group.

Varkkey H, Tyson A, Choiruzzad SAB. 2018. Palm oil intensification and expansion in Indonesia and Malaysia: environmental and socio-political factors influencing policy. Forest Policy and Economics.http://doi.org/10.1016/j.forpol.2018. 05.002. Hal: 148-159.

Wicke B, Sikkema R, Dornburg V, Faaij A. 2011. Exploring land use changes and the role of oil palm production in Indonesia and Malaysia. Land use policy. www.elsevier.com/locate/landusepol.

World Growth.2011. Manfaat Minyak Sawit bagi Perekonomian Indonesia.Palm Oil Green Development Campaign. 